\title{
The Construction Strategy of Ethnic Music Teaching System
}

\author{
Xiuhui Yu \\ Department of Music, Dongchang College of Liaocheng University, Shandong, China 252000
}

Keywords: music education; national music; national music education; cultural diversity

Abstract: The contemporary local music education model in China has certain problems. It is an educational model that is influenced and established under the Western music education system. It is out of touch with the traditional music culture in the actual development process. Therefore, in the process of music education with ethnic characteristics, it is necessary to pay more attention to the development of traditional music culture, and establish an independent and perfect Chinese music value system, and carry out local folk music teaching from the unique times background.

\section{Introduction}

A series of reasons, such as the transformation of the times, the inheritance of culture, and the development of history, have enabled contemporary students to present new features in the learning of the new era, especially in music. Under the influence of more and more Western students, China's primary and secondary schools at present, there is a large number of "foreign use" in the teaching of music. Students have made great changes in behavioral habits, ways of thinking, lifestyles, value systems, and world outlooks on life. Therefore, enriching and perfecting the local music literacy of students is like creating a "cardio tonic agent" in the student's study life, so that the students' music literacy and world outlook are more perfect, so as to meet the needs of students to grow up and become talented. It is one of the most important formulas in the "cardio tonic agent”.

\section{Current Status of Local Ethnic Music Education in China}

\subsection{National music teaching system faces challenges}

Since the twentieth century, the development of education and teaching of traditional local characteristics of music has been greatly impacted and changed. It is difficult to consider the innovation and development of music education in the face of a large number of Western cultures. It seems as if the small private school has been replaced by a large classroom in a hurry, and the folk songs have been replaced by Western tunes. The political and functional nature of music has also played a greater role in the development of the times. As shown in figure 1 below, it can be found: In some parts of China, in the process of education, the national music teaching with local characteristics is neglected, and students are made into a unified "product." 


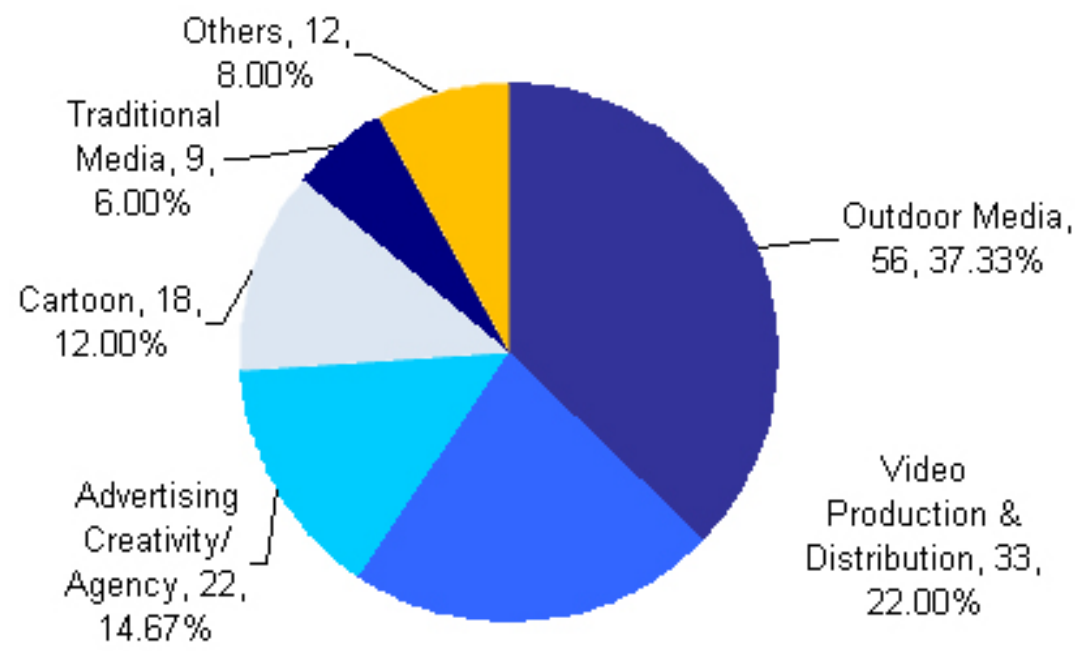

Figure 1 Distribution Table of Main Methods of Contemporary National Music Teaching

As shown in the teaching percentage diagram shown in Figure 1, you can find that this kind of teaching makes the wonderful music bring only the boring skill connection to the students, and becomes the machine for playing the piano. The music that has lost the connotation of ancient national culture will gradually lose the traditional culture in the current education of primary and secondary schools in China.

\subsection{The obvious problems in the teaching of national music}

In China, most of the education of characteristic national music is realized and developed in the music education of the school. School music education mainly includes professional music education and general music education. Professional music education is also called higher music education, and the corresponding general music education is distributed in the education of primary and secondary schools. In addition, the traditional virtues and cultural spirit of the Chinese nation are gradually lost in the contemporary group of college students. In recent years, the utilitarian and extravagant atmosphere of the campus has been spreading, and even the lack of students' sense of social responsibility and integrity has emerged. The phenomenon of faults inherited, and the emergence and development of these problems are also directly related to the disconnection of local music education.

\section{Reflections on the issue of local ethnic music education in China}

As a first-line music teaching worker, the author analyzes the current status of education and teaching of local ethnic music in China, and then thinks deeply:

- What position should ethnic music teaching occupy in music?

- How to make the local traditional national music of our country take root in teaching?

- How should national traditional culture be instilled and deepened in students' music learning?

As one of the important indicators for students to form their own values, local music should be the most effective place for students to improve their music literacy and develop their own abilities. At the same time, as the pillar of the country's future construction, the construction and improvement of the student's own value system has a certain relationship with its personal development, and even the development of society and nation.

At present, China has gradually moved toward a comprehensive well-off social form, economic 
field and social structure changes. They are relatively large, and the interest pattern and the comparison of ideas and concepts are also deepened, and affect students' ideological beliefs, value orientations and responsibilities and obligations to varying degrees. How to make the local traditional national music of our country take root in the music teaching of students, assisting and guiding contemporary students to build a correct outlook on life, values and music literacy is a problem that needs to be considered and solved.

\section{Specific Conception of Local Music Education with Local Characteristics in Accordance with Local Conditions}

In the process of music education and teaching, paying attention to the local characteristics of national music teaching has become the main trend of the development of contemporary international music teaching, and also pointed out in the 14th session of the International Music Education Society that "ethnic music education is an important factor in the development of national culture." Many countries currently carry out detailed ethnic music education planning through their own laws and procedures. However, it is imperceptible to develop local ethnic music education according to local conditions, and its educational function is more carried out during student learning activities.

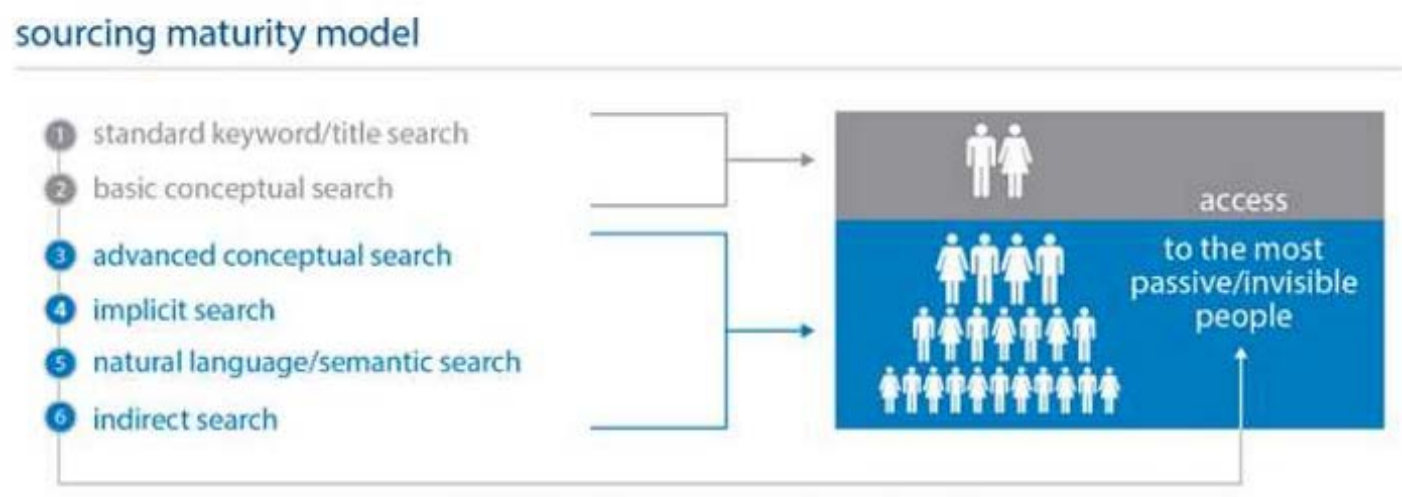

Figure 2 The specific conception of the national music education

From the above Figure 2, we can find that as the hope of the country's future, students are the main force of national development. Therefore, for the development of the country, it is very important for students' music literacy education and value training. Local music education is a public knowledge that does not pursue profitability and aims at the development of young people. It should provide opportunities for people of all ages to learn and lead development. The author believes that the development of local ethnic music education also has a certain ideological and political education function for students, which helps to guide the students' all-round development and class construction. It mainly includes the promotion of cultural literacy and historical heritage for the majority of students, the development of certain local characteristics of national music quality education for contemporary students, and also provides a way for students' scientific research services and tourism learning.

\section{How to inherit and carry forward the national music culture in the teaching of high school music}

\subsection{Cultivating teachers' rich ethnic music knowledge is the basis}

Before providing high-quality teaching to teachers, teachers must have a certain reserve of 
national music culture. Schools can regularly organize teachers to systematically learn the knowledge of related ethnic music, or arrange new media to display video and audio related to the development of national music. Teachers have a relatively broad teaching base. By mobilizing the enthusiasm of teachers, teachers can be full and wonderful when they teach. On the other hand, schools should also enrich the teachers' spare time as much as possible. Organized arrangements for teachers to participate in some music and cultural activities outside the school, and accumulate real talents in a wide range of applications.

\subsection{Innovative teaching courses are the main body}

After the teacher has accumulated a certain cultural heritage, the teacher should select the appropriate teaching materials to arrange the life-oriented curriculum for the students, so that the students can fully integrate into the appreciation and tasting of music. In the teaching process, students can survey students' favorite music tracks by means of questionnaires, and select classic and dissenting chapters to show them to students through multimedia. It is also possible to organize in groups to enable students to actively learn about different styles of ethnic music. It is possible to appropriately associate music tracks with other disciplines, and thus change the previous single teaching method. High school students have more complete musical literacy and expand their development potential.

Table $1 \mathrm{t}$-test of the teaching of national music in innovative teaching courses

\begin{tabular}{|c|c|c|c|c|c|}
\hline & College & average & $\begin{array}{l}\text { standard } \\
\text { deviation }\end{array}$ & $\mathrm{t}$ & $\mathrm{df}$ \\
\hline \multirow{3}{*}{$\begin{array}{l}\text { Environmental } \\
\text { integration ability }\end{array}$} & Economics & & & & \\
\hline & $\begin{array}{l}\text { Management Major } \\
\text { Non-administrative }\end{array}$ & 16.556 & 1.991 & 0.981 & 296 \\
\hline & major & 16.808 & 2.423 & & \\
\hline \multirow{3}{*}{$\begin{array}{l}\text { Business } \\
\text { Purposes }\end{array}$} & Major in Economics & & & & \\
\hline & and Management & 23.087 & 2.822 & 0.578 & 290 \\
\hline & major & 23.286 & 2.992 & & \\
\hline
\end{tabular}

For example, as shown in table 1 above, the overall influence of the national music teaching system on innovative teaching courses is still very large. High school music teaching can select the classic songs in "Beijing Opera Master Mei Lanfang", starting from the well-known Li Yugang's "New Guifei drunkenness" songs, and gradually guide students to develop music and sing, and stimulate students' interest in learning. To expand the artistic characteristics of Mei Pai represented by Mei Lanfang to the students, let the students feel their noble character and profound artistic achievements.

\subsection{Multiple music education is the key}

Because of the lack of methods for the correct appreciation of ethnic music, high school students will have some misunderstandings, even dislike and exclude national music. In the teaching of high school music, we must grasp the humanistic spirit and connotation of transmitting national music to students. Teachers can arrange for students to find homework, economic development, language style and other homework before class, to mobilize students' subjective initiative, let students experience the development and change of national culture in music, and experience the music house. The role and feelings brought. Through a variety of music education, students can 
understand and accept and carry forward the national culture.

\subsection{Organizing national music activities is an aid}

After a certain music knowledge education, students have certain knowledge of music culture. At this time, some small ethnic music activities can be organized appropriately, with the theme of promoting national music culture, and organizing some ethnic groups in the spirit of inheriting classics. The activities of traditional cultural development, through the independent participation and display of students, improve the music theory and cultural knowledge learned in the previous period, and experience and explore a wider range of national culture. [3] Organizing ethnic music activities is a more vivid and acceptable way to enrich students' musical literacy. Such small ethnic music activities can not only cultivate students' love for music, but also inject the national spirit into the life of students in a more lively way.

\section{Conclusions}

According to the talent development specifications aiming at "improving ability, perfecting quality, and pursuing innovation”, the local characteristics of the students' national music education needs to conform to the local educational characteristics, and carry out the construction of "traditional cultural strength" from a comprehensive perspective. In the process, the curriculum of local music education is added to enhance the overall concept of music, so that students can establish a perfect music literacy and value concept in the learning and growth of music courses, and let students get local music during the learning process. The cultivation of culture has made efforts for the development of students to become practical talents with both ability and political integrity.

\section{References}

[1] Jun M A, Duan X W, Xiao-Ming H E, et al. The Construction of National Physics Experimental Teaching Demonstration Center in the Ethnic Areas[J]. Research \& Exploration in Laboratory, 2014.

[2] Ma J. The Research on the Construction of Teaching Resources in Ethnic University in China.[J]. International Journal of Higher Education, 2015, 4.

[3] Wu C, Luo X, Wang T, et al. Safety Challenges and Improvement Strategies of Ethnic Minority Construction Workers: A Case Study in Hong Kong[J]. International Journal of Occupational Safety \& Ergonomics Jose, $2018: 1$. 